\title{
Induced sputum, bronchoalveolar lavage and blood from mild asthmatics: inflammatory cells, lymphocyte subsets and soluble markers compared
}

\author{
E. Pizzichini, M.M.M. Pizzichini, J.C. Kidney, A. Efthimiadis, P. Hussack, T. Popov, \\ G. Cox, J. Dolovich, P. O'Byrne, F.E. Hargreave
}

Induced sputum, bronchoalveolar lavage and blood from mild asthmatics: inflammatory cells, lymphocyte subsets and soluble markers compared. E. Pizzichini, M.M.M. Pizzichini, J.C. Kidney, A. Efthimiadis, P. Hussack, T. Popov, G. Cox, J. Dolovich, P. O'Byrne, F.E. Hargreave. CERS Journals Ltd 1998.

ABSTRACT: Airway inflammation in asthma can be measured directly by invasive bronchoalveolar lavage (BAL), directly and relatively noninvasively by induced sputum and indirectly from peripheral blood. We compared cellular and fluid phase indices of inflammation in induced sputum, BAL and blood from 11 adults with mild stable asthma.

On one day, induced sputum selected from saliva was collected and on the next, blood and BAL. Median results of sputum compared with BAL showed a higher number of nonsquamous cells $\left(5.3\right.$ versus $0.8 \times 10^{6}$ cells $\left.\cdot \mathrm{mL}^{-1}, \mathrm{p}=0.003\right)$, more neutrophils (34.3 versus $1.0 \%$, $p<0.001)$, CD4+ and CD19+ T-cells (76.5 versus $54.7 \%$, $\mathrm{p}=$ 0.01 and 5.2 versus $1.1 \%, p=0.03$, respectively), fewer macrophages $(60.3$ versus $95.0 \%, p=0.002)$ and markedly higher levels of eosinophil cationic protein (ECP) (264 versus $\left.2.0 \mu \mathrm{g} \cdot \mathrm{L}^{-1}, \mathrm{p}<0.001\right)$, tryptase $\left(17.6\right.$ versus $\left.2.2 \mathrm{UI} \cdot \mathrm{L}^{-1}, \mathbf{p}<0.001\right)$ and fibrinogen $\left(1,400\right.$ versus $\left.150 \mu \mathrm{g}^{-\mathrm{L}^{-1}}, \mathrm{p}=\mathbf{0 . 0 0 1}\right)$. Sputum and BAL neutrophils and CD4+ T-cells were strongly correlated. Sputum and BAL differed from blood by having higher proportions of T-cells (94.9 and $98.9 \%$ versus $87.7 \%, p=0.002)$ and lower proportions of CD19+ T-lymphocytes $(\mathrm{p}=\mathbf{0 . 0 4}$ and $\mathbf{0 . 0 0 6})$. Sputum also differed from blood by having higher proportions of CD4+ T-cells (76.5 versus $51.4 \%, \mathrm{p}=\mathbf{0 . 0 0 1})$, lower proportions of CD8+ cells $(24.0$ versus $40.3 \%, \mathrm{p}=\mathbf{0 . 0 4})$ and a higher $\mathrm{CD} 4+/ \mathrm{CD8}+$ ratio $(3.3$ versus 1.4 , $\mathrm{p}=\mathbf{0 . 0 1}$ ).

We conclude that in mild asthmatics, sputum, bronchoalveolar lavage and blood measure different compartments of inflammation. Induced selected sputum has the advantage over bronchoalveolar lavage of higher density of cell recovery and stronger signal for fluid-phase markers.

Eur Respir J 1998; 11: 828-834.
Asthma Research Group, Depts of Medicine and Paediatrics, St. Joseph's Hospital and McMaster University, Hamilton, Ontario, Canada.

Correspondence: F.E. Hargreave

Firestone Regional Chest and Allergy Unit St. Joseph's Hospital

50 Charlton Avenue East

Hamilton, Ontario, L8N 4A6

Canada

Fax: 19055216158

Keywords: Airway inflammation

asthma

blood

bronchoalveolar lavage

induced sputum

Received: August 151997

Accepted after revision February 41998

This study was supported by a grant from Astra Pharma Inc. EP and MMMP are supported by a Fellowship from CAPES, Ministry of Education, Brazil and Boehringer Ingleheim (Canada) Ltd.
Airway inflammation is an important determinant of asthma severity and eventual airway remodelling. Many recent studies using bronchoscopy to obtain bronchial biopsies and bronchoalveolar lavage (BAL), have demonstrated the inflammatory features of milder asthma including the accumulation of eosinophils, mast cells and lymphocytes and their activation markers [1,2]. The recent recognition that sputum can be processed to give reliable cell and fluid-phase measurements of inflammation [3,4] has resulted in the need to make comparisons with measurements in BAL, bronchial biopsies and blood. Four studies have compared induced sputum with BAL or bronchial biopsies with respect to cell counts [5-8], one of these has compared fluid-phase eosinophil cationic protein (ECP), albumin and mucin-like glycoprotein [5] and one has compared lymphocyte subsets and activation markers [8]. The results indicate that the specimens measured different compartments in the airways and that the magnitude of signal in one compartment does not necessarily correlate with that of another.
The present study was begun before the above reports were published. We compared inflammatory indices in induced sputum with those in BAL and blood in 11 mild clinically controlled asthmatics. The study differed from those mentioned above by selecting sputum from the expectorate to minimize the confounding influence of saliva on fluid-phase measurements, by measuring fluid-phase tryptase and fibrinogen and by comparing sputum and BAL lymphocyte subsets with those in peripheral blood.

\section{Methods}

\section{Subjects}

Eleven nonsmoking adults with stable asthma were recruited from patients and staff of the Firestone Regional Chest and Allergy Unit (table 1). All subjects had a diagnosis of asthma established symptomatically by episodic 
Table 1. - Patient characteristics

\begin{tabular}{|c|c|c|c|c|c|c|c|c|}
\hline \multirow{2}{*}{$\begin{array}{l}\text { Subject } \\
\text { No. }\end{array}$} & \multirow{2}{*}{$\begin{array}{l}\text { Age } \\
\text { yrs }\end{array}$} & \multirow{2}{*}{$\begin{array}{l}\text { Sex } \\
M / F\end{array}$} & \multirow[t]{2}{*}{ Smoking } & \multirow[t]{2}{*}{ Atopy* } & \multicolumn{2}{|c|}{$\mathrm{FEV}_{1}$} & \multirow{2}{*}{$\begin{array}{c}\mathrm{PC} 20 \\
\mathrm{mg} \cdot \mathrm{mL}^{-1}\end{array}$} & \multirow[t]{2}{*}{ Treatment } \\
\hline & & & & & $\mathrm{L}$ & $\%$ pred & & \\
\hline 1 & 63 & $\mathrm{M}$ & Ex & No & 2.8 & 83.5 & 1.3 & BUD $400+\beta_{2}$ p.r.n. \\
\hline 2 & 20 & $\mathrm{~F}$ & Non & Yes & 2.8 & 80.0 & 0.7 & BUD $300+\beta_{2}$ p.r.n. \\
\hline 3 & 27 & $\mathrm{~F}$ & Non & Yes & 3.3 & 108.0 & 3.6 & BUD $100+\beta_{2}$ p.r.n. \\
\hline 4 & 23 & $\mathrm{M}$ & Non & Yes & 4.9 & 111.0 & 1.2 & BUD $300+\beta_{2}$ p.r.n. \\
\hline 5 & 34 & M & Non & Yes & 4.2 & 99.3 & 0.8 & $\beta_{2}$ p.r.n. \\
\hline 6 & 23 & $\mathrm{~F}$ & Non & Yes & 3.1 & 88.3 & 6.1 & $\beta_{2}$ p.r.n. \\
\hline 7 & 26 & $\mathrm{~F}$ & Non & Yes & 3.0 & 91.7 & 1.9 & $\beta_{2}$ p.r.n. \\
\hline 8 & 21 & $\mathrm{M}$ & Non & Yes & 3.3 & 70.1 & 0.5 & $\beta_{2}$ p.r.n. \\
\hline 9 & 44 & M & Non & Yes & 2.9 & 76.5 & 0.3 & $\mathrm{BDP} 1000+\beta_{2}$ p.r.n. \\
\hline 10 & 27 & $\mathrm{M}$ & Non & No & 3.7 & 76.3 & 2.2 & $\beta_{2}$ p.r.n. \\
\hline 11 & 21 & $\mathrm{~F}$ & Non & Yes & 3.3 & 90.8 & 7.2 & $\beta_{2}$ p.r.n. \\
\hline
\end{tabular}

*: one or more positive allergy skin-prick tests. M: male; F: female; FEV1: forced expiratory volume in one second; \% pred: percentage of predicted value; $\mathrm{PC} 20$ : provocative concentration of methacholine causing a $20 \%$ fall in FEV1; Ex: exsmoker (>6 months); Non: nonsmoker; BUD: budesonide ( $\mu$ g.day-1); $\beta_{2}$ p.r.n.: inhaled $\beta_{2}$ agonist, as needed; BDP: beclomethasone dipropionate $\left(\mu \mathrm{g} \cdot \mathrm{day}^{-1}\right)$.

wheezing, chest tightness and/or dyspnoea and objectively confirmed by methacholine airway hyperresponsiveness (provocative concentration of methacholine causing a $20 \%$ fall in forced expiratory volume in one second $(\mathrm{PC} 20)<8 \mathrm{mg}$ when the forced expiratory volume in one second (FEV1) was Š70\% of predicted). The asthma was mild, as indicated by little or no airflow limitation after inhaled salbutamol $(200 \mu \mathrm{g})(\mathrm{FEV} 1 \mathrm{~S} 70 \%$ pred and FEV1/ VC Š $70 \%$ ) and mild to moderate airway hyperresponsiveness to methacholine (PC20 Š $0.25-<8.0 \mathrm{mg} \cdot \mathrm{mL}^{-1}$ ). None of the subjects was treated with an inhaled steroid at a dose $>1000 \mu \mathrm{g} \cdot$ day $^{-1}$ or had evidence of respiratory infection or an exacerbation of asthma symptoms in the previous 4 weeks. The study was approved by the hospital research committee and all subjects gave written informed consent.

\section{Study design}

This was a cross-sectional study. Subjects attended the laboratory for three visits at the same time of day. At the first visit, entry criteria were assessed by spirometry and a methacholine inhalation test and with sputum induction to confirm the ability of subjects to produce sputum. At the second visit, within a period of 2 weeks, further details were collected by questionnaire, and allergy skin-prick tests, electrocardiogram and chest radiography were performed. In addition, reversibility of airflow limitation was measured and sputum was induced. At the third visit, $24 \mathrm{~h}$ later, peripheral venous blood was collected and spirometry followed by fibreoptic bronchoscopy with BAL were performed. The main outcomes were: 1) sputum (obtained at visit 2) and BAL total cell counts, cell viability, eosinophils, neutrophils, macrophages, lymphocytes, metachromatic and bronchial epithelial cells, and fluid-phase ECP, fibrinogen and tryptase; and 2) sputum, BAL and peripheral blood lymphocyte subsets. Measurements were carried out by observers blind to other results.

\section{Clinical methods}

Spirometry was performed with a Collins water spirometer (Warren E. Collins, Inc., MA, USA). Baseline measurements of slow vital capacity (VC) and FEV1 were made according to American Thoracic Society criteria [9] and reference values were taken from CRAPO et al. [10]. Methacholine inhalation tests and allergy skin tests with 19 common allergen extracts were performed by standard procedures $[11,12]$. Venous blood was collected in an ethylenediamine tetra-acetic acid (EDTA) tube $\left(\mathrm{K}_{3}\right.$; Vacutainer BD, Rutherford, New Jersey, USA) and a differential white cell count was obtained using Coulter STKS (Courter Corp., Hialeah, FL, USA).

\section{Sputum induction}

Sputum was induced by the inhalation of hypertonic saline as described by PIN et al. [13]. Subjects were premedicated with inhaled salbutamol $(200 \mu \mathrm{g})$. The aerosol was generated by a Fisoneb ${ }^{\circledR}$ ultrasonic nebulizer (Canadian Medical Products Ltd., Markham, Ontario, Canada) with an output of $0.87 \mathrm{~mL} \cdot \mathrm{min}^{-1}$ and a mass median aerodynamic diameter of $5.58 \mu \mathrm{m}$. The method was slightly modified by inhaling increasing concentrations of saline (3, 4 and $5 \%$ ) for 7 min each through a mouthpiece without a valve or nose clips. After each inhalation period, an FEV1 value was measured for safety and the subjects were asked to blow their nose and rinse their mouth with water and swallow it to reduce contamination of the sputum specimen with post-nasal drip and saliva, and to try to cough sputum into a container.

\section{Bronchoscopy}

Fibreoptic bronchoscopy was performed using an Olympus BF-1T20D bronchoscope (Tokyo, Japan) to obtain BAL as previously described [14]. Briefly, fasting subjects withholding anti-asthma medications for $24 \mathrm{~h}$ had spirometry before and after salbutamol $(400 \mu \mathrm{g})$ inhaled from a pressurized inhaler. They received premedication with atropine $(0.6 \mathrm{mg}$ i.m. $)$ and topical anaesthesia of the upper airways was achieved with lidocaine gargle $(2 \mathrm{~mL}$ of $4 \%$ lidocaine solution for $60 \mathrm{~s}$ ) and four sprays of $1 \%$ lidocaine $\left(10 \mathrm{mg} \cdot\right.$ spray $\left.^{-1}\right)$. The nasal passages were lubricated with $2 \%$ lidocaine gel. Then the bronchoscope was passed through the nose to just above the glottis and $2 \mathrm{~mL}$ of $4 \%$ lidocaine solution was applied through the bronchoscope. 
The bronchoscope was then wedged in the right middle lobe or lingula and five aliquots of $20 \mathrm{~mL}$ of sterile normal saline at room temperature were instilled and aspirated with gentle hand suction. Pooled samples were kept on ice and processed within $30 \mathrm{~min}$.

\section{Sputum examination for cell content}

Sputum was selected from saliva [15] and processed within $2 \mathrm{~h}$ as described by Pizzichin et al. [3]. Briefly, sputum was treated with a volume $(\mathrm{mL})$ of $0.1 \%$ dithio-threitol (DTT) (Sputalysin 10\%, Calbiochem Corp., San Diego, CA, USA) equal to four times the weight (mg) followed by the addition of similar four volumes of Dulbecco's phosphate buffered saline (D-PBS). The suspension was filtered through a $48 \mu \mathrm{m}$ nylon mesh (B\&SH Thompson, Scarborough, Ontario, Canada) and the resulting suspension was used for total cell count (TCC) and cell viability. The cell suspension was adjusted to $1.0 \times 10^{6}$ cells $\cdot \mathrm{mL}^{-1}$, and cytospins were prepared in a Shandon III cytocentrifuge (Shandon Southern Instruments, Sewickley, PA, USA). The cytospins were stained with either Wright's or toluidine blue for differential and metachromatic cell counts. Cell counts were performed on 400 and 1,500 nonsquamous cells, respectively. The remaining cell suspension was centrifuged at 3,000 revolutions per minute (rpm) for $4 \mathrm{~min}$. The supernatant was aspirated and stored in Eppendorf tubes at $-70^{\circ} \mathrm{C}$ for later assays. The cell pellet was resuspended in D-PBS and used for flow cytometry.

\section{$B A L$ examination for cell content}

The volume of BAL fluid was recorded and centrifuged at $-4^{\circ} \mathrm{C}$ at 1,000 rpm for $10 \mathrm{~min}$. The supernatant was removed and stored at $-70^{\circ} \mathrm{C}$ for fluid-phase assays. The cell pellet was washed with D-PBS, centrifuged for $10 \mathrm{~min}$ at $1,000 \mathrm{rpm}$ and the supernatant discarded. The cell pellet was resuspended in $10 \mathrm{~mL}$ of D-PBS. Total cell counts, viability, differential cell counts and metachromatic cell counts were performed as described for sputum. The remaining suspension was used for flow cytometry.

\section{Flow cytometry in blood, sputum and BAL}

Flow cytometry was performed using a two-colour FACScan Analyzer (Becton Dickinson, Mississauga, Ontario, Canada). The instrument was calibrated using CaliBRITE beads and AutoCOMP software (Becton Dickinson, Missisauga, Ontario, Canada) for setting the photomultiplier tube voltages in order to obtain the correct mean fluorescence intensity, set the fluorescence compensation and check the instrument sensitivity. Blood lymphocytes were phenotyped by standard dual-colour flow cytometry procedures. Sputum and BAL cells were incubated in the dark at room temperature with $10 \mu \mathrm{L}$ of monoclonal antibody for $15 \mathrm{~min}$. The monoclonal antibodies used were conjugated to fluoroscein isothiocyanate (FITC) and phycoerythrin (PE). The panel consisted of: CD3/CD19, CD3/ CD4, CD3/CD8, and immunoglobulin (Ig)G1/IgG2a (Becton Dickinson). Postincubation cells were washed with phosphate buffered saline (PBS) and fixed with $0.5 \mathrm{~mL}$ of
0.9\% paraformaldehyde. Acquisition of data was with a single argon ion laser, $488 \mathrm{~nm}$ FACScan Analyzer (Becton Dickinson). Lymphocytes were distinguished on the basis of cell size (forward scatter) and cell granularity (side scatter). In sputum, to enhance the number of lymphocytes for analysis an acquisition gate was set using the lower third of the side scatter field. Ten thousand cells were acquired in list mode and further analysed using the CONSORT 30 software (Becton Dickinson) and a Hewlett-Packard (HP 9000 series 302) computer (Fort Collins, USA). In sputum and BAL, because of contamination with debris, CD3/CD19 lymphocytes could not be expressed as a percentage of the gate, but were recorded as a percentage of the cells detected by fluorescence [16]. We therefore expressed blood CD3/CD19 lymphocytes in the same way for comparison. Analysis was based on a minimum of 2,000, 400 and 3,000 lymphocytes in blood, sputum and BAL, respectively.

\section{Soluble markers in sputum and BAL}

The concentrations of ECP and tryptase in the thawed supernatant were determined using a sensitive radioimmunoassay (RIA, Kabi Pharmacia Diagnostics AB, Uppsala, Sweden). Fibrinogen was measured by a "sandwich" enzyme-linked immunosorbent assay (ELISA) assay using a rabbit anti-human fibrinogen antibody (Dako A080 (Dako Diagnostics, Mississauga, Ontario, Canada)). The limit of detection for the fluid-phase assays were $2.0 \mu \mathrm{g} \cdot \mathrm{L}^{-1}, 0.79$ $\mathrm{ng} \cdot \mathrm{mL}^{-1}$ and $2 \mathrm{IU} \cdot \mathrm{mL}^{-1}$ for ECP, fibrinogen and tryptase, respectively. The results of sputum measurements were adjusted for the dilution factor of the procedure [3].

\section{Data analysis}

Results are reported as median and interquartile range (IQR) calculated using weighted averages. Significance was accepted at the level of 95\%. Dependent variables with non-normal distribution were log transformed before analysis. Differences between induced sputum and BAL cells and fluid-phase markers were examined by paired t-test. Differences between induced sputum, BAL and peripheral blood lymphocyte subsets were tested by repeated measures analysis of variance (ANOVA); the source of significant variation was identified by the Student-Newman Keuls procedure to adjust the significance for multiple comparisons [17]. The agreement between measurements was calculated by intraclass correlation co-efficient (R) [18] and graphically displayed as suggested by BLAND and AltMan [19]. The correlations were examined by Spearman rank correlation coefficient $\left(r_{s}\right)$. Only correlations with an $r_{s}$ value above 0.50 and a p-value $ð 0.01$ were considered significant.

\section{Results}

Measurements in sputum, BAL and peripheral blood were performed successfully in all but one patient who did not have a suitable sputum sample for flow cytometry. Both sputum induction and BAL procedures were well tolerated by all subjects. 


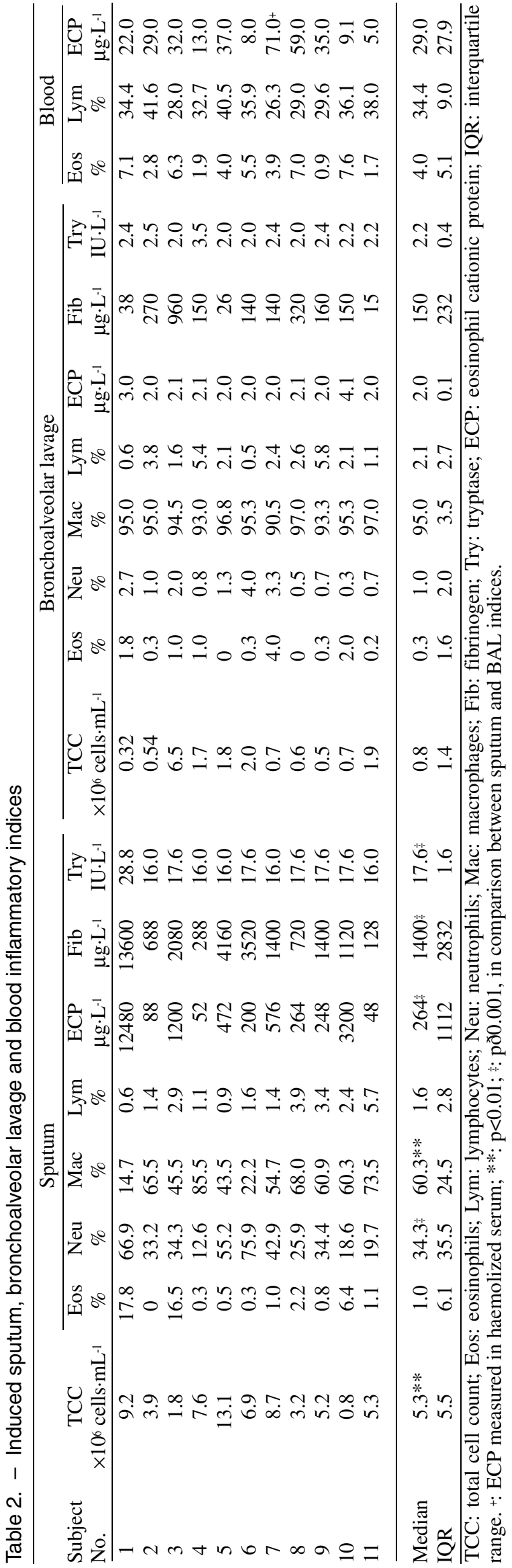

\section{Sputum versus BAL cells}

Cells in sputum and BAL had good and similar viability (78.5 (17) versus 78.2 (11.9)\%, $\mathrm{p}=0.9)$. In comparison with BAL, sputum had more cells per millilitre $(\mathrm{p}=0.003)$ and a higher proportion of neutrophils $(\mathrm{p}<0.001), \mathrm{CD} 4+$ and CD19+ T-cells ( $p=0.01$ and $p=0.03$, respectively). Compared with BAL, sputum had higher CD4+/CD8+ T-lymphocyte ratios (3.3 (4.3) versus 1.3 (1.6), $\mathrm{p}=0.02$ ) (tables 2 and 3, fig. 1). The proportion of macrophages was lower ( $\mathrm{p}=0.002$ and $\mathrm{p}=0.04$, respectively) (fig. 1 ) and there was no statistically significant difference in the proportion of eosinophils $(\mathrm{p}=0.1)$ or lymphocytes $(\mathrm{p}=0.9)$ (table 2 , fig. 1), metachromatic cells $(1.0(0.2)$ versus 0 $(0.5) \%, \mathrm{p}=0.1)$ and bronchoepithelial cells $(0(0.5)$ versus $0(0.5) \%, \mathrm{p}=0.6)$. Significant positive correlations were observed between sputum and BAL neutrophils and sputum and BAL CD4+ lymphocytes only (fig. 2). With the exception of cell viability $(r=0.6)$ and $C D 3+$ lymphocytes $(\mathrm{r}=0.75)$, the agreement of these cells in sputum and BAL was poor ( $R<0.5$ for all) (fig. 1$)$.

\section{Sputum versus BAL fluid-phase markers}

Sputum fluid-phase levels of ECP $(\mathrm{p}<0.001)$, tryptase $(\mathrm{p}<0.001)$ and fibrinogen $(\mathrm{p}=0.001)$ were higher than in BAL (table 2, fig. 1). Sputum ECP correlated with the proportion $\left(\mathrm{r}_{\mathrm{s}}=0.78, \mathrm{p}=0.004\right)$ and the absolute number $\left(r_{s}=0.71, p=0.01\right)$ of sputum eosinophils (fig. 3). The correlations between BAL ECP and eosinophils, either proportion $\left(\mathrm{r}_{\mathrm{s}}=0.4, \mathrm{p}=0.1\right)$ or absolute number $\left(\mathrm{r}_{\mathrm{s}}=0.23, \mathrm{p}=\right.$ 0.4 ), were not significant (fig. 3). The agreement between these markers in sputum and BAL was also poor (fig. 1).

\section{Sputum and/or BAL versus blood lymphocyte subsets}

CD3+ T-lymphocytes were higher in sputum and BAL than in peripheral blood ( $\mathrm{p}=0.002$ for both comparisons) (table 3). CD4+ T-lymphocytes ( $\mathrm{p}=0.01$, table 3 ) and CD4+/ CD8+ ratio (3.3 (4.3) versus $1.5(1.6), \mathrm{p}=0.01)$ were higher in sputum than blood while CD8+ cells were lower ( $\mathrm{p}=0.04$, table 3). There were no significant correlations between sputum or BAL lymphocyte subsets measurements on the one hand and peripheral blood lymphocyte subsets on the other.

\section{Discussion}

The results demonstrate that induced sputum contains a greater proportion of neutrophils and CD4+ T-cells and higher concentrations of ECP, tryptase and fibrinogen than BAL in subjects with mild controlled asthma. While the proportion of these cells correlated between the two specimens, the levels of fluid-phase components did not. The proportion of eosinophils correlated with the levels of fluid-phase ECP in sputum but not in BAL. Both sputum and BAL had more T (CD3+) lymphocytes than peripheral blood and sputum had more CD4+ T-cells and B (CD19+) cells. These data support and add to those in previous reports [5-8]. They indicate that the results from different specimens measure different compartments and, 
Table 3. - Induced sputum, bronchoalveolar lavage (BAL) and blood inflammatory indices

\begin{tabular}{|c|c|c|c|c|c|c|c|c|c|c|c|c|}
\hline \multirow[b]{2}{*}{$\begin{array}{l}\text { Subject } \\
\text { No. }\end{array}$} & \multicolumn{4}{|c|}{ Sputum \% } & \multicolumn{4}{|c|}{ BAL \% } & \multicolumn{4}{|c|}{ Blood \% } \\
\hline & CD3 & CD19 & CD4 & $\mathrm{CD} 8$ & CD3 & CD19 & CD4 & CD8 & CD3 & CD19 & CD4 & CD8 \\
\hline 1 & 98.8 & 1.1 & 69.1 & 28.1 & 99.3 & 1.2 & 38.1 & 52.7 & 94.7 & 5.3 & 41.6 & 63.8 \\
\hline 2 & 92.3 & 7.7 & 45.9 & 53.4 & 92.3 & 0.7 & 31.4 & 66.6 & 92.9 & 7.1 & 51.4 & 43.5 \\
\hline 3 & 94.8 & 5.2 & 84.3 & 16.2 & 97.6 & 2.4 & 59.7 & 36.5 & 87.7 & 12.3 & 57.7 & 38.3 \\
\hline 4 & 99.6 & 0.4 & 62.4 & 41.3 & 99.7 & 0.3 & 49.6 & 47.0 & 91.1 & 0.3 & 44.8 & 42.1 \\
\hline 5 & 97.7 & 2.3 & 87.1 & 12.2 & 98.9 & 1.1 & 71 & 29.2 & 91.9 & 8.1 & 57.1 & 42.1 \\
\hline 6 & 92.7 & 7.3 & 78.8 & 20.1 & 96.7 & 3.3 & 64.6 & 31.9 & 69.8 & 4.8 & 33.0 & 30.2 \\
\hline 7 & 94.9 & 5.1 & 89.9 & 8.2 & 97.7 & 2.3 & 66.7 & 27.7 & 82.9 & 17.1 & 65.0 & 35.3 \\
\hline 8 & 94.2 & 5.8 & 81.3 & 18.6 & 99.3 & 0.7 & 45.5 & 49.4 & 86.0 & 14.0 & 66.9 & 28.7 \\
\hline 9 & 98.8 & 1.2 & 74.1 & 27.9 & 99 & 1.0 & 66.7 & 28.9 & 95.2 & 4.8 & 35.3 & 64.0 \\
\hline 10 & 93.2 & 6.8 & 36.4 & 47.2 & 93.2 & 6.8 & 36.4 & 47.2 & 58.6 & 9.0 & 40.2 & 16.9 \\
\hline 11 & NA & NA & NA & NA & 99.3 & 0.6 & 70.1 & 27.1 & 82.1 & 17.9 & 58.6 & 40.3 \\
\hline Median & $94.9 \div 8$ & $5.2 \ddagger$ & 76.5 \% & $24.0 \S$ & $98.9 \S$ & $1.1 \S$ & 59.7 & 36.5 & $\begin{array}{l}87.7 \\
\end{array}$ & 8.1 & 51.4 & 40.3 \\
\hline IQR & 5.7 & 5.8 & 26.7 & 27.6 & 2.6 & 1.7 & 28.6 & 20.5 & 10.8 & 9.2 & 18.4 & 13.2 \\
\hline
\end{tabular}

NA: not available; IQR: interquartile range; $: \mathrm{p}<0.05$ between sputum and blood; $\$$ : $\mathrm{p}<0.05$ between BAL and blood.
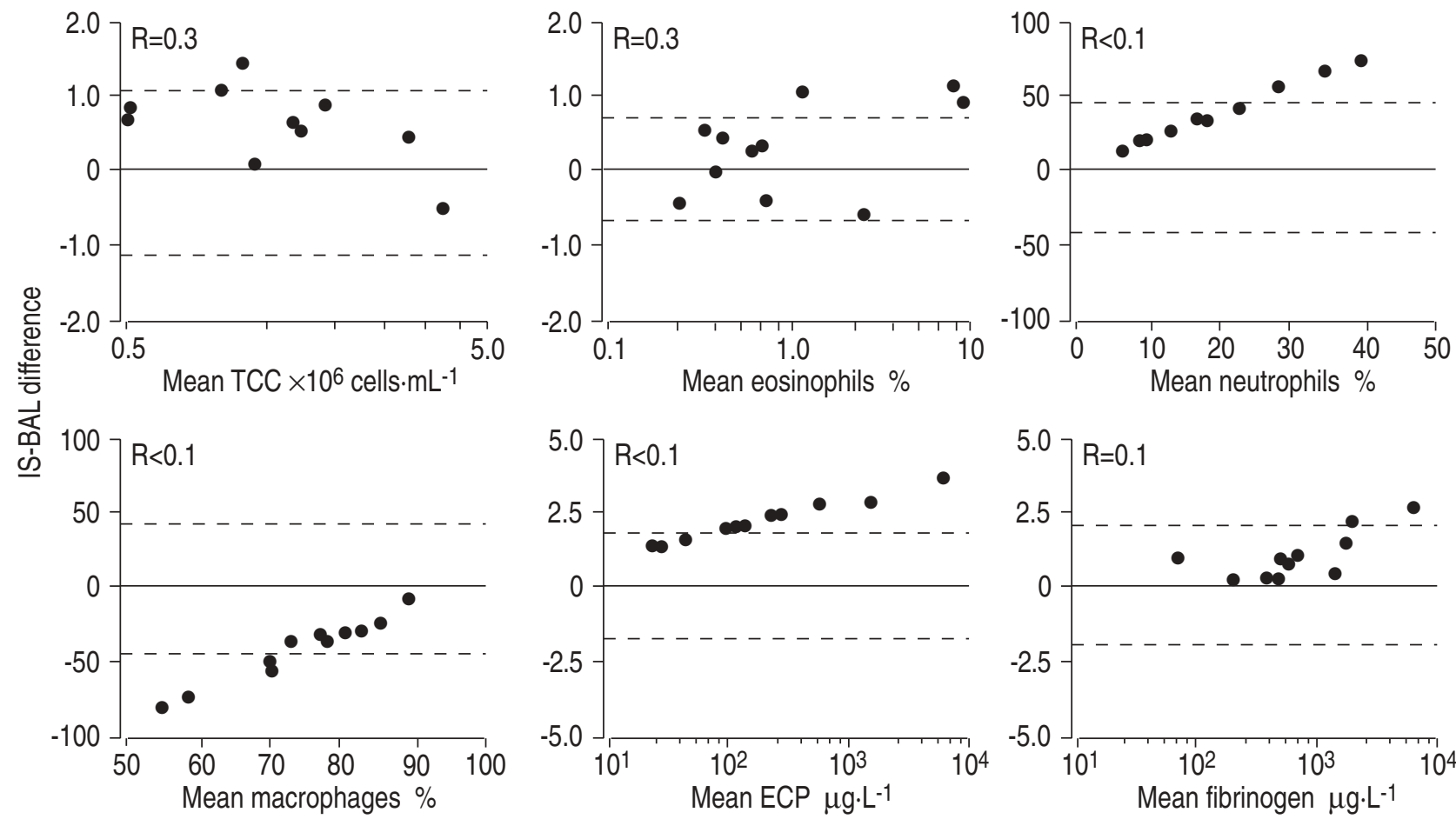

Fig. 1. - The differences (log values except for neutrophils and macrophages) between induced sputum (IS) and bronchoalveolar lavage (BAL) total cell count (TCC), eosinophils, neutrophils, macrophages, eosinophil cationic protein (ECP), and fibrinogen are plotted as a function of the mean of two values. Intraclass correlation coefficients $(\mathrm{R})$ are shown. $\_$: mean difference; - - - : \pm 2 sD of mean difference.

thus, may not necessarily correlate. In addition, the observed correlations, or lack thereof, may be due to subject selection, the measurement property of the specimen and the confounding influence of diluting fluids with sputum and BAL specimens.

This study was designed to minimize confounding factors. The sputum was induced $24 \mathrm{~h}$ before BAL to minimize day-to-day variability. It seems unlikely that this procedure would alter the BAL counts. This is supported by the observations of FAHY et al. [5] who compared BAL markers after sputum induction in five asthmatic subjects using a volume of hypertonic saline three times the volume we used, without differences compared with a previous baseline BAL. We have carried out examination of sputum selected from the remainder of the expectorate to minimize dilution with saliva, using a method which is very efficient in doing this [15]. We could not, however, avoid the influence of the variable dilution of the lavage fluid on the BAL fluid-phase levels.

The subjects selected for the study had asthma that was controlled and stable. As a result, the proportion of eosinophils in sputum was normal in seven of 11 subjects. This may explain why the proportion of eosinophils was not higher in sputum than in BAL. The higher proportion of neutrophils in sputum and the higher proportion of macrophages in BAL is the same as that observed in other studies [5-8]. The results reflect the compartmental nature of the specimens. Qualitative and quantitative differences in inflammatory cells between the first $50 \mathrm{~mL}$ of lavage and BAL [5, 7, 8, 14] or between bronchial mucus [20] 

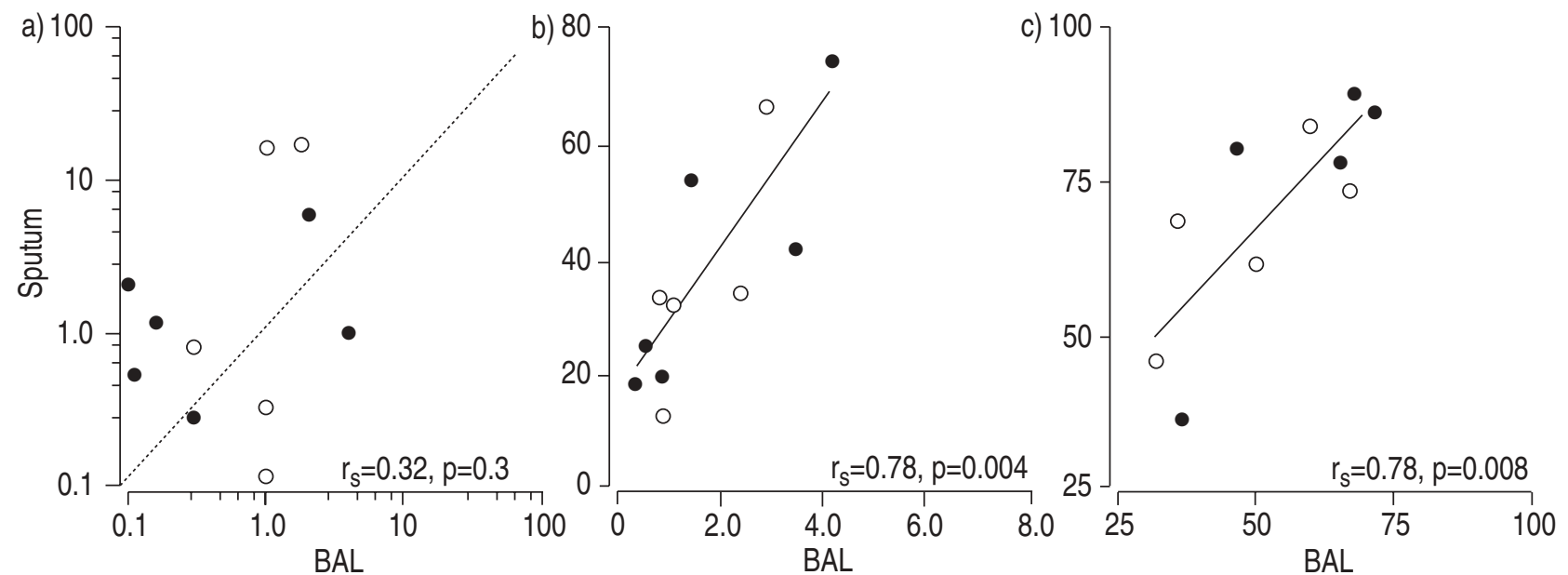

Fig. 2. - Correlations between induced sputum and bronchoalveolar lavage (BAL) for percentages of: a) eosinophils; b) neutrophils; and c) CD4+ Tlymphocytes. $\bigcirc$ : patients receiving inhaled steroids; - - - : line of identity; —_: regression line.
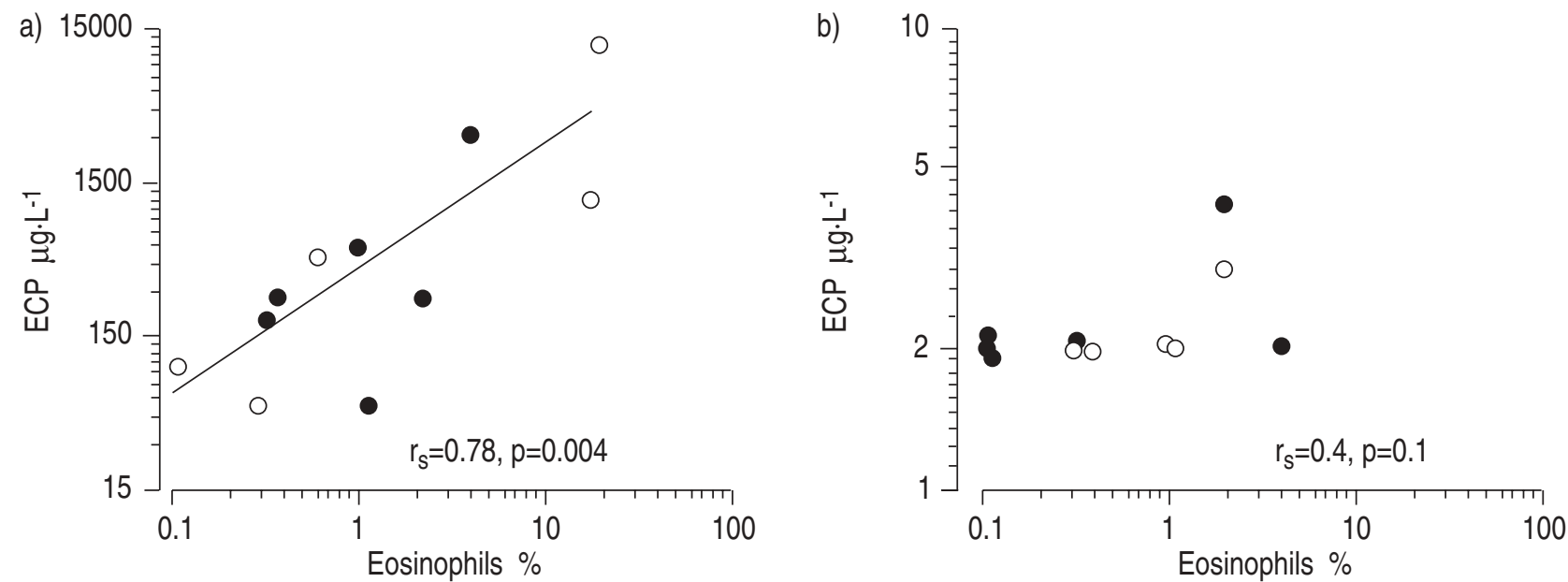

Fig. 3. - Correlations between sputum eosinophils and eosinophil cationic protein (ECP) in a) induced sputum and b) bronchoalveolar lavage (BAL). Solid line is the calculated regression line for linear regression. A strong and highly significant correlation was observed between eosinophils and ECP measured in induced sputum. No correlation was found between the same markers measured in BAL. O: asthmatics receiving inhaled corticosteroids. $\mathrm{r}_{\mathrm{s}}$ : Spearman rank correlation coefficient.

and BAL suggest that sputum samples the larger airways while BAL particularly samples the peripheral airways. Why there was not a greater proportion of lymphocytes in BAL in the present study is not clear; one wonders whether it was a result of the smaller volume of lavage (100 $\mathrm{mL}$ ) than used in other reports.

The measurement properties of the method of sputum examination we used, particularly reliability [3], are excellent. The repeatability of sputum specific cell counts [3], and lymphocyte subsets [16] is high, while the repeatability of cells and soluble markers in BAL, with the exception of eosinophils, is poor [21, 22]. Highly repeatable instruments are those with a high signal to noise ratio [23] which is accomplished with the method of sputum examination we used. In contrast, BAL has a low signal to noise ratio, which results from variability in lavage and recovered fluid [24-26]. This may explain why there was a good correlation between the low numbers of eosinophils and ECP levels in sputum but not in lavage.

In the present study we have demonstrated increased proportions of T-lymphocytes in induced sputum and
BAL, and significantly higher proportions of CD4+ and CD19+ T-cells in sputum than BAL and peripheral blood. In agreement with a previous report by GROOTENDORST et al. [8] the proportion of CD4+ cells in induced sputum correlated with those in BAL. The same correlations were not observed with peripheral blood. This is not surprising since peripheral blood is less likely to reflect the inflammatory process in the airways $[27,28]$. The higher concentration of T-cells in the airways is in keeping with the role of lymphocytes in the pathogenesis of asthma and it is in agreement with other studies examining lymphocyte subsets by flow cytometry in BAL [29] or induced sputum [30]. The lower proportions of B-cells in sputum in comparison with our previous report [16] may be a result of subject selection.

In conclusion, inflammatory indices in induced sputum selected from the expectorate differ from those in bronchoalveolar lavage and blood and do not necessarily correlate. These partially confirm the findings of other studies comparing bronchoalveolar lavage with induced expectorate. The differences between studies may be a 
result of differences in subject characteristics and differences in the sputum and bronchoalveolar lavage samples examined. The lack of correlations between specimens may reflect different properties of each instrument or the type of airway sampling. If the first is present, these differences indicate that the instrument with better properties is superior because it enables more reliable measurements. If the later is true, and both instruments have similar properties, the measurements in each of the specimens give complementary information. These issues can be further evaluated by comparing the ability of each method to measure longitudinal changes in airway inflammation after an intervention.

\begin{abstract}
Acknowledgements: The authors wish to thank the patients who participated in this study, S. Evans for performing the fluid-phase measurements and Pharmacia Diagnostics AB, Uppsala, Sweden for providing the ECP and tryptase kits.
\end{abstract}

\section{References}

1. Jeffery P. Bronchial biopsies and airway inflammation. Eur Respir J 1996; 9: 1583-1587.

2. Smith DL, Deshazo RD. Bronchoalveolar lavage in asthma. An update and perspective. Am Rev Respir Dis 1993; 148: 523-532.

3. Pizzichini E, Pizzichini MMM, Efthimiadis A, et al. Indices of airway inflammation in induced sputum: reproducibility and validity of cell and fluid phase measurements. Am J Respir Crit Care Med 1996; 154: 808-817.

4. in't Veen JCCM, de Gouw HWFM, Smits HH, et al. Repeatability of cellular and soluble markers of inflammation in induced sputum from patients with asthma. Eur Respir J 1996; 9: 2441-2447.

5. Fahy JV, Wong H, Liu J, Boushey HA. Comparison of samples collected by sputum induction and bronchoscopy from asthmatic and healthy subjects. Am J Respir Crit Care Med 1995; 152: 53-58.

6. Maestrelli P, Saetta M, Di Stefanno A, et al. Comparison of leukocyte counts in sputum, bronchial biopsies and bronchoalveolar lavage. Am J Respir Crit Care Med 1995; 152: 1926-1931.

7. Keatings VM, Evans DJ, O'Connor BJ, Barnes PJ. Cellular profiles in asthmatic airways: a comparison of induced sputum, bronchial washing, and bronchoalveolar lavage fluid. Thorax 1997; 52: 372-374.

8. Grootendorst CD, Sont JK, Willems LNA, et al. Comparison of inflammatory cell counts in asthma: induced sputum versus bronchoalveolar lavage and bronchial biopsies. Clin Exp Allergy 1997; 27: 769-779.

9. American Thoracic Society (statement). Standardization of spirometry - 1987. Update. Am Rev Respir Dis 1987; 136: $1285-1298$.

10. Crapo RO, Morris AH, Gardner RM. Reference spirometric values using techniques and equipment that meets ATS recommendation. Am Rev Respir Dis 1981; 123: 659-694.

11. Juniper EF, Cockcroft DW, Hargreave FE. Histamine and methacholine inhalation tests: A laboratory tidal breathing protocol. Lund, Sweden, Astra Draco AB, 1994.

12. Pepys J. Skin tests in diagnosis. In: Gell PGH, Coombs RRD, Lachman PJ, eds. Clinical Aspects of Immunology. 3rd ed. Oxford, Blackwell Scientific Publications, 1975; pp. 55-80.

13. Pin I, Gibson PG, Kolendowicz R, et al. Use of induced sputum cell counts to investigate airway inflammation in asthma. Thorax 1992; 47: 25-29.

14. Kirby JG, Hargreave FE, Gleich GJ, O'Byrne PM. Bronchoalveolar cell profiles of asthmatic and nonasthmatic subjects. Am Rev Respir Dis 1987; 136: 379-383.

15. Pizzichini E, Pizzichini MMM, Efthimiadis A, Hargreave FE, Dolovich J. Measurement of inflammatory indices in induced sputum: effects of selection of the sputum to minimize salivary contamination. Eur Respir J 1996; 9: 1174-1180.

16. Kidney JC, Wong AG, Efthimiadis A, et al. Elevated Bcells in sputum of asthmatics. Close correlation with eosinophils. Am J Respir Crit Care Med 1996; 153: 540-544.

17. Glantz SA, Slinker BK. Repeated measures. In: Glantz SA, Slinker BK, eds. Primer of Applied Regression and Analysis of Variance. New York, McGraw-Hill, Inc. Health Professions Division, 1990; pp. 381-420.

18. Norman GR, Streiner DL. Repeated-measures ANOVA and reliability of measurement. In: Norman GR, Streiner DL, Eds. Biostatistics. The Bare Essentials. St Louis, Mosby Year Book Inc., 1994; p. 90.

19. Bland JM, Altman DG. Statistical methods for assessing agreement between two methods of clinical measurement. Lancet 1986; i: 307-310.

20. Diaz P, Galleguillos FR, Gonzalez MC, Pantin CFA, Kay $\mathrm{AB}$. Bronchoalveolar lavage in asthma: the effect of disodium cromoglycate (cromolyn) on leukocyte counts, immunoglobulins, and complement. J Allergy Clin Immunol 1984; 74: 41-48.

21. Ward C, Gardiner PV, Booth H, Walters EH. Intrasubject variability in airway inflammation sampled by bronchoalveolar lavage in stable asthmatics. Eur Respir J 1995; 8: 1866-1871.

22. Ward C, Gardiner PV, Booth H, Walters EH. Variability of markers of airway inflammation sampled in BAL. Letter reply. Eur Respir J 1996; 9: 2700-2701.

23. Norman GR. Reliability. In: Streiner DL, Norman GR, ed. Health Measurement Scales: A Practical Guide to Their Development and Use. 2nd ed. Oxford, Oxford University Press, 1975; pp. 104-127.

24. Rennard S, Basset G, Lecossier D, O'Donnell K, Martin P, Crystal RG. Estimation of volume of epithelial lining fluid recovery by lavage using urea as a marker of dilution. J Appl Physiol 1986; 60: 532-538.

25. Ward C, Duddridge M, Fenwick J, et al. Evaluation of albumin as a reference marker of dilution in bronchoalveolar lavage fluid from asthmatics and control subjects. Thorax 1993; 48: 518-522

26. Baughman RP. The uncertainties of bronchoalveolar lavage. Eur Respir J 1997; 10: 1940-1942.

27. Pizzichini E, Pizzichini MMM, Dolovich J, Hargreave FE. Measuring airway inflammation in asthma: eosinophils and ECP in induced sputum compared with peripheral blood. J Allergy Clin Immunol 1997; 99: 539-544.

28. Pizzichini MMM, Pizzichini E, Clelland L, et al. Sputum in severe exacerbations of asthma: kinetics of inflammatory indices after prednisone treatment. Am J Respir Crit Care Med 1997; 154: 1501-1508.

29. Gratziou C, Carroll M, Walls A, Howarth PH, Holgate ST. Early changes in T-lymphocytes recovered by bronchoalveolar lavage after local allergen challenge of asthmatic airways. Am Rev Respir Dis 1992; 145: 1259-1264.

30. Louis R, Shute J, Biagi S, et al. Cell infiltration, ICAM-1 expression, and eosinophil chemotatic activity in asthmatic sputum. Am J Respir Crit Care Med 1997; 155: 466472. 